Original Research Article

\title{
Prescription pattern and rationality of drugs study of patients of OPD (outpatient) of orthopedics Department of RKDF Medical College Hospital and Research Centre, Bhopal, MP, India
}

\author{
Rajeev Dalela ${ }^{1}$, Prashant Wadagbalkar ${ }^{2 *}$, Hareshwar Kumar Mali ${ }^{1}$, Swati Raipurkar ${ }^{3}$
}

\begin{abstract}
${ }^{1}$ Department of Orthopedics, RKDF Medical College Hospital and Research Centre, Bhopal, Madhya Pradesh, India ${ }^{2}$ Department of Pharmacology, RKDF Medical College Hospital and Research Centre, Bhopal, Madhya Pradesh, India ${ }^{3}$ Department of Paediatrics Index Medical College Hospital Research Centre, Indore, Madhya Pradesh, India
\end{abstract}

Received: 21 October 2016 Accepted: 17 November 2016

*Correspondence to: Dr. Prashant Wadagbalkar, Email: drprashantw@gmail.com

Copyright: () the author(s), publisher and licensee Medip Academy. This is an openaccess article distributed under the terms of the Creative Commons Attribution NonCommercial License, which permits unrestricted noncommercial use, distribution, and reproduction in any medium, provided the original work is properly cited.

\begin{abstract}
Background: To study the prescription pattern of drugs prescribed to patients of OPD of orthopedics department and to analyze the rationality of drugs prescribed by doctors of RKDF MCHRC, Bhopal, MP, India.

Methods: A prospective, observational study was planned for 200 patients selected in the year 2015. Collected data were entered in a predesigned forms downloaded from WHO website. Rationality of drugs prescription was analyzed using WHO drug utilization and prescription indicators. For generic drugs reference NLEM 2011 and for cost analysis, Drug Today 2014 was used.

Results: out of 200 patients, $41 \%$ were male and 59\% were female. Average numbers of drugs prescribed per prescription was 3.3. Most commonly prescribed drug was Analgesics an Anti-inflammatory (37.1\%) in oral as well as Intramuscular injections and Topical forms, Gastric acid inhibitors (15.4\%), Muscle relaxants $(12.1 \%)$ Calcium and Vitamin D, glucosamines $(12.1 \%)$, Antimicrobials (8\%), Steroids (1.8\%), Enzyms serratiopeptidase (1.8\%). Most commonly prescribed Analegsic was FDC of Trypsin+ Rutoside+ Bromelin+ Diclofenac $(30.6 \%)$ followed by FDC Acceclofenac+ Paracetamol+ Seratiopeptidase (15.9\%), followed by FDC Tramaodol+ Paracetamol (11\%).

Drugs prescribed in generic form were $0 \%$.Average cost of treatment was INR 600 per prescription. Most common route of drug prescription was 1 . Oral route $81.7 \%$. 2. Topical $6.4 \%$. 3. Injectable intramuscular $6.2 \%$ and intra articular $5.7 \%$. Duration of treatment was prescribed in $81 \%$. Frequency of drug administration was mentioned in $100 \%$ of prescriptions. EDL prescription was $81 \%$. FDCs were $35 \%$.

Conclusions: There was Poly pharmacy. Drugs prescribed in generic form were very low. Drugs prescribed from NLEM were $81 \%$. CMEs on Rational drug therapy to doctors working in orthopedics department should be conducted to promote rational use.
\end{abstract}

Keywords: Essential drug list, Generic, Indian drug review, Rational, WHO prescription indicators

\section{INTRODUCTION}

According to WHO "Rational use of drugs requires that patients receive medications appropriate to their clinical needs, in doses that meet their own individual requirements for an adequate period of time ,at the lowest cost to them and their community". ${ }^{1}$
Drug utilization and prescription pattern studies done in variety of hospitals denote the prescription trends prevailing in that hospitals which is influenced by many factors including the knowledge and experience of the prescribing doctor. These types of studies help us know the prevailing trends of drugs being used, in addition we can study the rationality of drugs being used Prescription audit helps in Rational use of medicines (RUM)., 
This type of prescription pattern study was never carried in this hospital, so it was planned to conduct prescription pattern study of drugs as per WHO drug prescription indicators, and to find rationality of drugs use in this set up after obtaining clearance from institutional ethics and research committee.

\section{METHODS}

After applying inclusion and exclusion criteria, 200 OPD patients were selected for this prospective observational study in the year 2015.Demographic data was then entered in pre decided forms.

\section{Inclusion criteria}

Patients coming to OPD of orthopaedics department mainly.

\section{Exclusion criteria}

Those OPD patients who were later admitted in wards of orthopaedics department/other referred patients to orthopaedics department by other departments.

In a predesigned form, demographic data, OPD number, age, sex, generic or branded drugs, dose, duration and route of drug administration, whether from essential drug list or not, diagnosis, coexisting conditions /diseases, their treatment ere noted.

Generic name and cost of the drugs was evaluated using drug today.

\section{Statistical analysis}

Statistical analysis was done for descriptive analysis was done by SPSS version 2.0.

\section{RESULTS}

1. Demographic distribution of 200 patients of OPD, Orthopedics, RKDF MCHRC.

\section{Sex}

- Male -82(41\%)

- Female-118 (59\%)

\section{Age}

- Below $15=(10 \%)$

- Between $15-30=(10 \%)$

- Between 30-45= $(25 \%)$

- Between $45-60=(30 \%)$

- Above $60=(25 \%)$
Table 1: Causes of visit to orthopaedics OPD.

\begin{tabular}{|c|c|c|c|}
\hline $\begin{array}{l}\text { S. } \\
\text { No }\end{array}$ & Condition & Diseases & $\begin{array}{l}\% \text { of OPD } \\
\text { visits }\end{array}$ \\
\hline \multirow{6}{*}{1} & \multirow{6}{*}{$\begin{array}{l}\text { Cold } \\
\text { orthopaedics } \\
\mathrm{N}=161=80 \%\end{array}$} & Various Arthritis & 28 \\
\hline & & $\begin{array}{l}\text { Numbar radicular } \\
\text { pain }\end{array}$ & 24 \\
\hline & & cervical pain & 16 \\
\hline & & planter fasciitis & 8.1 \\
\hline & & multiple joints & 2.4 \\
\hline & & Misc Tenis Elbow & 1.6 \\
\hline \multirow{6}{*}{2} & \multirow{6}{*}{$\begin{array}{l}\text { Fracture } \\
\text { complications } \\
N=30=15 \%\end{array}$} & Fracture Wrist & 4.5 \\
\hline & & Fracture Femur I/T & 3.7 \\
\hline & & Forearm & 2.2 \\
\hline & & $\begin{array}{l}\text { Fracture Femur } \\
\text { Neck }\end{array}$ & 2.2 \\
\hline & & Fracture shoulder & 1.5 \\
\hline & & Fracture Misc & 0.7 \\
\hline 3 & $\begin{array}{l}\text { Misc, AVN, } \\
\text { CTEV } \\
\mathrm{N}=10=5 \%\end{array}$ & AVN/CTEV/MISC & 5 \\
\hline
\end{tabular}

\section{Causes of visit to $O P D$}

1. Cold orthopedics- $(80 \%)$

- Inclusive of various arthritis $28 \%=$ (osteoarthritis knee 22.4\%, Rhematoid Arthritis 4.2\%,Gen Arthritis 1.4\%).

- Lumbar radicular pain=24\%

- Cervical pain=16\%

- Planter fasciitis $=8.1 \%$

- Multiple joints $=2.4 \%$

- Misc, Tenis elbow etc $=1.6 \%$

2. Fractures follow up /new-15\%

- Wrist $=4.5 \%$

- Intertrochantric femur $=3.7 \%$

- Forearm $=2.2 \%$

- Neck femur $=2.2 \%$

- Around shoulder $=1.5 \%$

- $\mathrm{Misc}=0.7 \%$

\section{Misc-AVN/CTEV/Rare- 5\%}

\section{Associated diseases}

1. Hypertension- $20 \%$

2. Diabetes- $10 \%$

3. Angina/MI- 5\%

Total number of patients- 200

Total number of drugs prescribed- 660

Average drugs per prescription was 3.03. 
Table 2: Overall prescribed drugs.

\begin{tabular}{|c|c|c|c|c|c|}
\hline $\begin{array}{l}\text { Sr. } \\
\text { No. }\end{array}$ & Drug given orally, $\mathbf{n}=539$ & Number & Total & $\begin{array}{l}\% \text { Of } \\
\text { Oral }\end{array}$ & $\begin{array}{l}\% \text { of Total } \\
\text { drugs }\end{array}$ \\
\hline 1 & $\begin{array}{l}\text { Analgesics alone+ FDC of analgesics+Trypsin, Rutoside, } \\
\text { Bromolein, Serratiopeptidase }\end{array}$ & 188 & & $34 \%$ & 28.4 \\
\hline 2 & Gastric acid inhibitor, Antacids & 102 & & $18.9 \%$ & 15.4 \\
\hline 3 & Muscle relaxants, & 80 & & $15 \%$ & 12.1 \\
\hline 4 & $\begin{array}{l}\text { Calcium,Vitamin D, B12, Glucosamines, Trace elements, } \\
\text { Nutritional supplements }\end{array}$ & 80 & & $15 \%$ & 12.1 \\
\hline 5 & Antimicrobials & 53 & & $10 \%$ & 8.0 \\
\hline 5 & Steroids & 12 & & $2.3 \%$ & 1.8 \\
\hline 6 & Enzumes, Serratiopeptidase, etc & 13 & & $2.2 \%$ & 1.8 \\
\hline \multirow[t]{2}{*}{7} & Misc, DMARD/gout drugs & 11 & & $2.0 \%$ & 1.8 \\
\hline & Total & & 539 & $100 \%$ & $81.7 \%$ \\
\hline \multicolumn{6}{|c|}{ Topical $=6.4 \% \mathrm{n}=42$} \\
\hline & Name & & Number & $\begin{array}{l}\% \text { of } \\
\text { Topical }\end{array}$ & \\
\hline 1 & Providone Iodine & 21 & & $51 \%$ & 3.2 \\
\hline 2 & $\begin{array}{l}\text { Topical Analgesics/counterirritants- } 49(7.8 \%) \\
\text { Topical gels containing Diclofenac, Methyl Salicylate, Camphor, } \\
\text { Menthol, Methyl Nicotinate, TrolamineSalicylate, } \\
\text { Capsaicin,Transdermal Fantanyl patches are used in inflammatory } \\
\text { conditions }\end{array}$ & 16 & & $39 \%$ & 2.5 \\
\hline \multirow[t]{2}{*}{3} & Framycetin sulfate, Silver sulfadiazine & 5 & & $10 \%$ & 0.7 \\
\hline & Total & & 42 & $100 \%$ & $6.4 \%$ \\
\hline \multicolumn{6}{|c|}{ Intramuscular injections $6.2 \% \mathrm{n}=41$} \\
\hline 1 & Diclofenac injections intramuscular & 41 & 41 & $100 \%$ & $6.2 \%$ \\
\hline \multicolumn{6}{|c|}{ Intraarticular injections $5.7 \% \mathrm{n}=38$} \\
\hline 1 & Steroids, Triamcinilone intraarticular & 38 & 38 & $100 \%$ & $5.7 \%$ \\
\hline Grai & Total & & 660 & & $100 \%$ \\
\hline
\end{tabular}

Total number of patients -200, Total number of drugs prescribed-660

Average drugs per prescription was 3.3, Oral $=81.7 \%$

Table 3: Dosage forms of analgesics, anti-inflammatory, enzymes.

\begin{tabular}{|c|c|c|c|c|c|c|}
\hline $\begin{array}{l}\text { Sr. } \\
\text { No. }\end{array}$ & $\begin{array}{l}\text { Dosage form } n= \\
245=100 \%\end{array}$ & & No & $\begin{array}{l}\% \text { of oral } \\
\text { analgesic }\end{array}$ & $\begin{array}{l}\% \text { of total } \\
\text { anal } \\
\text { gesics }\end{array}$ & $\begin{array}{l}\% \text { of } \\
\text { total } \\
\text { drugs }\end{array}$ \\
\hline \multirow{7}{*}{1} & \multirow{7}{*}{$\begin{array}{l}\text { Oral, Analgesics } \\
\mathrm{n}=188=76.7 \%\end{array}$} & Trypsin+Rutoside+Bromelin+Diclofenac & 75 & 39.8 & 30.6 & \\
\hline & & Acceclofenac+Paracetamol+Seratiopeptidase & 39 & 20.7 & 15.9 & \\
\hline & & Tramaodol+Paracetamol & 27 & 14.8 & 11.0 & \\
\hline & & Etodolac & 21 & 11.7 & 8.6 & \\
\hline & & Piroxicam & 22 & 12.2 & 8.5 & \\
\hline & & Misc, Indomethacin, Nimesulide, etc & 4 & 2.5 & 1.6 & $28.4 \%$ \\
\hline & & Oral Total & 188 & $100 \%$ & $76.6 \%$ & \\
\hline 2 & $\begin{array}{l}\text { Injectables } \\
\mathrm{n}=41=16.7 \%\end{array}$ & Diclofenac & 41 & & $16.7 \%$ & $6.2 \%$ \\
\hline 3 & $\begin{array}{l}\text { Topical Analgesics } \\
\text { counterirritants } \\
\mathrm{n}=16=6.5 \%\end{array}$ & $\begin{array}{l}\text { Containing Diclofenac+ Methyl sal, Camphor, } \\
\text { Menthol, Capsaicin, Trolamine } \\
\text { salicylate/Transdermal Fantanyl patches }\end{array}$ & 16 & & $6.5 \%$ & $2.4 \%$ \\
\hline Total & 245 & & 245 & & $100 \%$ & $37.1 \%$ \\
\hline
\end{tabular}

Oral $=188$, Injectable $=41$

Topical $=16$

Total $=245=245 / 660=37.1 \%$ of all drug encounters were with analgesics and anti-inflammatory 
Overall Drugs prescribed were route of drug administration

1. Oral- $81.7 \%$

2. Injectable, Intramuscular- $6.2 \%$

3. Topical- $6.4 \%$

4. Intraarticular- $5.7 \%$

\section{Drugs given}

Oral

1. Analgesics Alone and FDC containing Analgesics, Antiinflammatory drugs+ Enzymes-seratiopeptidase, trypsin, chymotrypsin, Rutoside, Bromolein-188 (28.4\%).

2. Gastric acid inhibitors- $102(15.4 \%)$.

Ranitidine (3.1\%), Rabeprazole (6\%), Pantoprazole (3.3\%), Esmoprazole (1.5\%), Omeprazole (1.5\%).

3. Muscle relaxants- $80(12.1 \%)$.

Chlorzoxazone (4.8\%), Thiocolchicoside (4.2\%) Methocarbamol (2.4\%), Misc. (0.7\%) Tizanidine, Gabapentin, Pregabalin, Espirone.

4. Supplements, Vitamin D+ calcium- 80 (12.1\%).

5. Antimicrobials- 53 (8\%).

Amoxiclav- (2.1\%), Linezolid- (2.4\%), Third gen Cephalosporins- $(2.5 \%)$, (Cefoperazone-1.5\%, Cefixime$(1.0 \%)$, Ofloxacin- $(0.7 \%)$, Misc- $(0.3 \%)$

6. Steroids-12 (2.3\%)- Deflazocort.

7. Enzymes- Seratiopeptidase, Trypsin, Chymotrypsin, Rutoside, Bromolein- 13(1.8\%)

8. Topical Analgesics/counterirritants/Antimicrobials$42-(6.4 \%)$.

Topical gels containing Diclofenac, Methyl Salicylate, Camphor, Menthol, Methyl Nicotinate, Trolamine Salicylate, Capsaicin, Transdermal Fantanyl patches are used in inflammatory conditions/Povidone iodine/framycetin sulfate/silver sulfadiazine.

9. Misc, DMARD- $11(1.8 \%)$

10. Intramuscular Injections-Diclofenac- 41 (6.2\%)

11. Intraarticular Injections-Triamcinolone- 38 (5.7\%)

Most commonly prescribed oral NSAIDS combination was Trypsin+ Rutoside+ Bromelin+ Diclofenac given in $28.4 \%$.

Table 4: Antimicrobials on OPD basis only oral dosage forms.

\begin{tabular}{|c|c|c|c|c|c|}
\hline Sr. No. & Dosage form & Antimicrobial $n=53$ & Number & $\%$ of Antimicrobials & $\%$ of total drugs \\
\hline \multirow{5}{*}{1} & \multirow{5}{*}{$\begin{array}{l}\text { Oral } n=53 \\
8 \% \text { of total drugs } \\
10 \% \text { of oral drugs } \\
\text { given } 100 \% \text { oral }\end{array}$} & Cefoparazone, Cefixime & 12 & 20.7 & $1.8 \%$ \\
\hline & & Amoxicillin+Clavulonoic & 12 & 22.6 & $1.8 \%$ \\
\hline & & Linezolid & 15 & 28.3 & $2.3 \%$ \\
\hline & & Ofloxacin & 6 & 9.4 & 0.9 \\
\hline & & Misc & 8 & 15.0 & 1.2 \\
\hline & & Total & 53 & $100 \%$ & $8 \%$ \\
\hline
\end{tabular}

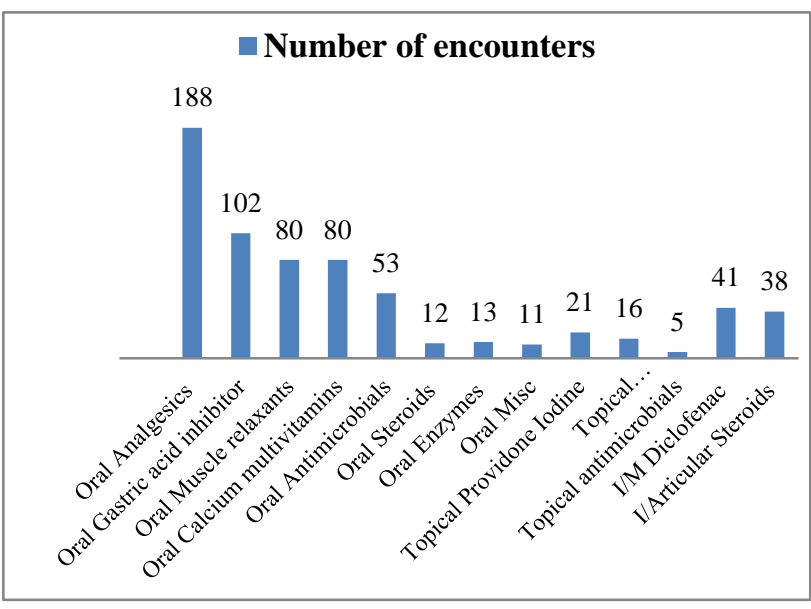

Figure 1: Drug distribution in orthopaedics OPD.
The frequency of drug administration was recorded in $100 \%$ of prescriptions. The duration of treatment was mentioned in $81 \%$ prescriptions.

\section{WHO drug prescription indicators}

1. Number of drugs per prescription $=3.3$

2. Percentage of generic drugs $=0 \%$

3. Percentage of encounters with antibiotics $=10 \%$

4. Percentage of injections $=11.9 \%$

5. Percentage of essential drugs $=81 \%$

6. Cost per prescription $=$ Rs. $600 /-$

\section{DISCUSSION}

Polypharamcy is very common. Number of drugs per prescription is 3.3 which is higher than the WHO guideline of 2.02, similar studies in other hospitals in 
India mention $5.3 \%$ in srividya, Bithi $4.3 \%$ while in Ubedulla and Ingle studies it was around $3{ }^{4-7}$ Ideally the number of drugs per prescription should be low so that incidence of drug interactions and adverse effects would also be low but practically Polypharmacy is the usual practice. The intention of orthopaedic surgeons is to ensure better compliance.

Analgesics (37.1\%) were the most commonly prescribed drugs in oral, injectable and topical forms, followed by peptic acid inhibitors (18.9\%, Muscle Relaxants (15\%), multi Vitamin D Calcium, Glucosamine (14.8\%), Antimicrobials (10\%), Steroids (2.3\%), Serratiopeptidase enzyme preparations $(2.2 \%)$.

Of all analgesics, Trypsin+ Rutoside+ Bromelin+ Diclofenac (NSAID) Oral fixed drug combinations was more commonly prescribed $(30.6 \%)$ than, Diclofenac. This was in difference with Muraiah and Elsy where Tramodol was used more than Diclofenac. ${ }^{8,9}$ In Choudhary DK study shows Diclofenac to be more common. $^{10}$

Co prescribed with Analgesics, Proton pump inhibitors $(15.4 \%)$ were very commonly prescribed while this in in Srividya (17.5\%) and Kumars study. ${ }^{11}$

Nutritional supplements, multi Vitamins and Calcium $(12.1 \%)$ were more than with Shankar's study. ${ }^{12}$

Topical Analgesics/counterirritants/Antimicrobials-were given to 42 (6.4\%) Encounters.

Topical gels containing Diclofenac, Methyl Salicylate, Camphor, Menthol, Methyl Nicotinate, Capsaicin, Trolamine Salicylate, Transdermal Fantanyl patches are used in inflammatory conditions. While Topical Povidone iodine/Silver Sulfadiazine/ Framycetin were prescribed as antimicrobials.

Steroids were given in $2.3 \%$ of patients, $80 \%$ oral Deflozacart and $20 \%$ injectable Intraarticular (Triamcinolone). We could not find any comparative data in reference studies.

Drugs prescription by generic names is very low in this study $(0 \%)$ all drugs were prescribed by branded names only similar to Patel study while WHO guideline is to prescribe drugs by generic names is $100 \%{ }^{13,14}$ In srividya studies generic prescription was $61 \% .^{3}$ Other studies also confirm the low percentage of (0-4\%) generic drugs prescription of frequent meetings of medical representatives of branded pharmaceutical companies insisting on branded drugs. ${ }^{4,5}$ While generic drugs are much cheaper to afford by patients, these generics should be more used to curb the cost of the treatment.

Percentage of encounters with antibiotics is $10 \%$ in line with WHO guidelines. These medicines add to microbial resistance and extra cost to prescription. These are prescribed without any culture and sensitivity. Other studies mention low use of antibiotics. ${ }^{4,5}$

Percentage of injectable in outpatient department is $11.9 \%$. This is more than WHO guideline of less than $10 \%$ injectables. ${ }^{11}$ In Afsan's study it was $3 \% .{ }^{15}$ Most of the drugs prescribed in OPD practice are through oral route $(81.7 \%)$. Injections are used more in admitted IPD, ward patients $(46 \%){ }^{3}$

FDCs, fixed drug combinations in our study was around $35 \%$, very high in OPD practice. This is more than srivdya studies (18.5\%). ${ }^{3}$ There is a tendency on the part of prescribers to write FDC as it ensures better patient compliance but at the same time chances of adverse drug effects are also more.

Given together steroids, analgesics, antibiotics cause more adverse effects. ${ }^{6}$

A drug prescribed from NLEM was $81 \%$.

Average cost per prescription is Rs. 600 INR. This increases when patients are admitted and require medicines for longer period.

There is a need to conduct such studies on larger number of patients. Prescription audit studies should be periodically conducted to assess the effect of training on rational drug therapy which still has challenges. ${ }^{16}$

\section{Strength of the study}

Prospective study, better to research.

\section{Limitations}

Single centre study, study duration was long, prospective study; everyone involved loses interest monotonous large resources were required.

\section{CONCLUSION}

Polypharamcy is very common in OPD. Number of drugs per prescription is 3.3 which are higher than the WHO guideline of 2.02.Drugs prescription by generic names should be promoted. Routine use of antibiotics should be after proper culture and sensitivity testing. Injectable given in OPD should be lower than 10\%.Drugs prescribed from essential drug list should be promoted. Topical gels should be preferred over oral ones.

For promoting rational drug therapy, Pharmacology faculties should also visit orthopaedics department to know the various area of improvement.

Regular CMEs on Rational drug prescription should be held by pharmacologists for orthopaedic surgeons in a creative, indirect suggestive way, without hurting anyone's ego and self-respect. Ultimate beneficiary is the 
patient. In any hospital the best interest is the patient's interest.

This type of study will help surgeons of orthopaedics department/ pharmacologists/ health/ hospital care authorities in policy making.

\section{ACKNOWLEDGEMENTS}

Thankful to Faculties, Dr. Katare, Resident and OPD clerical staff of Orthopaedics, RKDF MCHRC, for helping, collecting data and filling the forms of the study.

\section{Funding: No funding sources}

Conflict of interest: None declared

Ethical approval: The study was approved by the Institutional Ethics Committee

\section{REFERENCES}

1. WHO. How to investigate drugs use in health facilities: selected drug use indicators, Geneva, World Health Organization, WHO/ DAP/93 1993;1:1-87.

2. Kaur S, Rajgopalan S, Kaur N, Shafiq N, Bhalla A, Pandhi P, et al. Drug utilization study in medical emergency unit of a tertiary care hospital in North India.Emerg Med Int. 2014;973578.

3. Ramgopal. Prescription auditing and drug utilization pattern in a tertiary care teaching hospital of western UP. Int J Basic Clin Pharmacol. 2012;1(3):184-90.

4. Srividya BP, Shashikumar NS, Amardeep G. Retrospective audit of prescription of drugs among inpatients of orthopedic wards at Medical College Teaching Hospital, Mandya. Natl J Physiol Pharm Pharmacol. 2016;6:282-5.

5. Bithi. Drug Utilization study in orthopedic units, Dhaka, Bangladesh, International current pharm journal. 2014,3(9):315-21.

6. Ubedulla S, Sekhar NC, Jayasree T, Shankar J, Rohit K. Prescription trends in department of orthopedics at tertiary care teaching hospital. J Chem Pharm Res. 2013;5(11):512-7.

7. Ingle P, Patil P, Lathi V. Study of rational prescribing and dispensing of prescriptions with NSAIDs in orthopedic OPD. AJPCR. 2015;8(4).
8. Muraraiah S, Rajarathna K, Vishwanath M, Ramaswamy A, Kamath S, Seshu S, et al. Evaluation of WHO prescribing indicators among orthopaedic inpatients at a tertiary care hospital J Chem Pharm Res. 2014;6(8):278-80.

9. Elsy MI, Ajitha KN, Sanalkumar KB, Jyothish K, Kuttichira P. Prescribing pattern of analgesics in orthopaedic department of an Indian tertiary care teaching hospital in Kerala. Kerala Med J. 2011;4:149-520.

10. Choudhary DK, Bezbaruah BK. Prescription pattern of analgesics in orthopedic in patient department at tertiary care hospital in Guwahati ,Northeast India,Indian J Pharmacol. 2016;48:377-81.

11. Kumar A, Dalai CK, Ghosh AK, Ray M. Drug utilization study of coadministration of nonsteroidal anti-inflammatory drugs and gastroprotective agents in an orthopaedics outpatients department of a tertiary care hospital in West Bengal. Int J Basic Clin Pharmacol. 2013;2(2):199-202.

12. Shankar PR, Pai R, Dubey AK, Upadhyay DK. Prescribing patterns in the orthopaedics outpatient department in a teaching hospital in Pokhara, western Nepal. Kathmandu Univ Med J. 2007;5(1):16-21.

13. Patel V, Vaidya R, Naik D, Borker P. Irrational drug use in India: a prescription survey from Goa. J Postgrad Med. 2005;51(1):9-12.

14. World Health Organization. International Network for Rational Use of Drugs and World Health Organization. How to Investigate Drug Use in Health Facilities: Selected Drug Use Indicators 1993. EDM Research Series No. 7 1993;192.

15. Afsan M, Haque MME, Alam MM, Noor N. Audit of prescribing practices to evaluate rational use of medicines in the OPD of orthopaedics in a private medical college hospital. J Shaheed Suhrawardy Med Coll. 2012;4(2):39-42.

16. Thawani V. Rational use of medicines: achievements and challenges. Indian J Pharmacol. 2010;42:63.

Cite this article as: Dalela R, Wadagbalkar P, Mali HK, Raipurkar S. Prescription pattern and rationality of drugs study of patients of OPD (outpatient) of orthopedics Department of RKDF Medical College Hospital and Research Centre, Bhopal, MP, India. Int J Basic Clin Pharmacol 2017;6:117-22. 